\title{
Modelling stand basal area growth for radiata pine plantations in Northwestern Spain using the GADA
}

\author{
Fernando CASTEDo-DorAdo ${ }^{\mathrm{a} *}$, Ulises DiÉGUEZ-ARANDA ${ }^{\mathrm{b}}$, Marcos BARRIO-ANTA $^{\mathrm{c}}$, \\ Juan Gabriel ÁLVAREZ-GONZÁLEZ ${ }^{\mathrm{b}}$
a Departamento de Ingeniería y Ciencias Agrarias, Universidad de León, Escuela Superior y Técnica de Ingeniería Agraria, Campus de Ponferrada, 24400 Ponferrada, Spain
b Departamento de Ingeniería Agroforestal, Universidad de Santiago de Compostela, Escuela Politécnica Superior, Campus universitario, 27002 Lugo, Spain

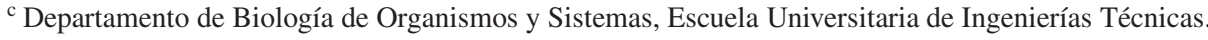
C/ Gonzalo Gutiérrez de Quirós, 33600 Mieres, Spain

(Received 14 June 2006; accepted 18 October 2007)

\begin{abstract}
A stand basal area growth system for radiata pine (Pinus radiata D. Don) plantations in Galicia (Northwestern Spain) was developed from data corresponding to 247 plots measured between one and five times. Six dynamic equations were considered for analysis and both numerical and graphical methods were used to compare alternative models. The equation that best described the data was a dynamic equation derived from the Korf growth function by the generalized algebraic difference approach (GADA) and by considering two parameters as site-specific. This equation was fitted in one stage by the base-age-invariant dummy variables method. The system also incorporated an equation for predicting initial stand basal area, expressed as a function of stand age, site index, and the number of trees per hectare. This information can be used to establish the starting point for the projection equation when no inventory data are available. The effect of thinning on stand basal area growth was also analyzed and the results showed that the same projection equation can be used to obtain reliable predictions of unit-area basal area development in thinned and unthinned stands.
\end{abstract}

stand basal area projection / stand basal area initialization / dummy variables method / generalized algebraic difference approach / thinning effect

Résumé - Modélisation de la croissance en surface terrière de plantations de Pinus radiata dans le Nord-ouest de l'Espagne. Un système d'équations modélisant la croissance en surface terrière a été développé pour des plantations de Pinus radiata D. Don en Galice (Nord-ouest de l'Espagne) à partir des données recueillies dans 247 placettes mesurées entre une et cinq fois. Six équations dynamiques ont été analysées et des méthodes graphiques et numériques ont été employées pour comparer des modèles alternatifs. Une équation dynamique dérivée de la fonction de croissance de Korf, dont les deux paramètres spécifiques à la station sont estimés par l'approche de la différence algébrique généralisée (GADA), décrit le mieux les données. L'équation a été ajustée en une seule étape en utilisant la méthode des variables indicatives indépendantes de l'âge. En outre, pour prédire la surface terrière initiale, le système incorpore aussi une fonction de l'âge du peuplement, de l'indice de fertilité de station et du nombre d'arbres à l'hectare. Cette information peut être utilisée pour fixer l'état initial de l'équation de projection quand les données d'inventaire ne sont pas disponibles. L'effet de l'éclaircie sur la croissance en surface terrière a également été analysé et les résultats montrent que la même équation de projection peut être utilisée pour prédire de façon fiable l'évolution de la surface terrière dans les peuplements non éclaircis et les peuplements éclaircis.

projection de la surface terrière / initialisation de la surface terrière / méthode des variables indicatives / approche généralisée de la différence algébrique / effet de l'éclaircie

\section{INTRODUCTION}

According to the Third National Forest Inventory of Spanish forests [70], radiata pine (Pinus radiata D. Don) plantations occupy a total surface area of approximately 90000 ha in Galicia. The oldest stands of this species in the region were planted in the 1940s, and plantations are currently being established at a rate of 6000 ha per year [1]. This makes radiata pine one of the three most commonly used species, along with Eucalyptus nitens Maiden and E. globulus Labill., in reforestation programmes, particularly those involving abandoned agricultural land. The wide distribution and the high growth rate

* Corresponding author: fcasd@unileon.es of the species have also made it very important in the forestry industry in northern Spain, with an annual harvest volume of $505000 \mathrm{~m}^{3}$ in the period 1992-2001 [70]. Two different silvicultural regimes are usually applied in the region. Low density regimes, characterized by initially low stocking densities at plantation (1200-1300 trees ha ${ }^{-1}$ followed by two heavy thinnings, resulting in values of the relative spacing index of $0.20-0.22$. The high density regime corresponds to initial tree densities of between 2100-2500 trees ha ${ }^{-1}$, and 3-4 light thinnings to maintain the relative spacing index at values of $0.13-$ 0.15 . Rotation ages usually vary from 25 to 35 years depending on the site quality of the stand and on the purpose of the timber. 
Sánchez et al. [60] developed a static ${ }^{1}$ stand-level growth and yield model for the species in Galicia based on data from the first inventory of a network of permanent plots, which provides rather limited information about the forest stand. As more inventories of the network of permanent plots were available, a dynamic ${ }^{1}$ whole-stand growth model has been constructed. Several submodels have been developed to date: (i) a merchantable volume equation [15], (ii) a diameter distribution function [14], (iii) a mortality model [2], (iv) a site quality system [27], and (v) a generalized height-diameter model $[16,45]$. The remaining submodel is a stand basal area growth system. The dynamic whole-stand growth model would be used for a variety of purposes including inventory updating, harvest scheduling and prediction of wood yields for different stand conditions.

The stand basal area growth system is a key component of whole-stand-level models, since stand basal area is directly related to other very important economic variables, such as total stand volume and quadratic mean diameter [69]. Furthermore, estimations from stand basal area growth equations can be used to constrain size-class or individual tree models, and thus form a link between high and low resolution models $[32,36]$.

Stand basal area growth functions must possess three main properties so that consistent estimates can be obtained $[4,26$, 68]: biological meaning, path-invariance and simplicity. The gross stand basal area function must have an asymptotic value when the projected stand age approaches infinity $[3,6]$. The projection function must be path-invariant, which implies that for the same unthinned growth period, the result of projecting firstly from $t_{0}$ to $t_{1}$, and then from $t_{1}$ to $t_{2}$, must be the same as that of the one-step projection from $t_{0}$ to $t_{2}$. Finally, the models must be parsimonious, because models that are too complex and include many interactions between independent variables may be unstable and have a poor predictive capacity.

Fulfilment of these properties depends on both the construction method and the mathematical function used to develop the model. Most of them can be achieved by use of the Algebraic Difference Approach (ADA) proposed by Bailey and Clutter [7] or its generalization (GADA) of Cieszewski and Bailey [22]. The GADA can be applied in modelling the growth of any site dependent variable involving the use of unobservable variables substituted by the self-referencing concept [51] of model definition [21], such as dominant height, stand basal area, stand volume, number of trees per unit area, stand biomass or stand carbon sequestration (e.g., $[9,21])$.

The objective of the present study was to develop a stand basal area growth system for radiata pine plantations in Galicia (northwestern Spain). A stand basal area projection function for different types of stands (thinned and unthinned) was developed by use of the GADA. A stand basal area initialization model was developed for establishing the stating point for the

\footnotetext{
${ }^{1}$ Static growth models attempt to predict directly the course over time of the quantities of interest (volumes, mean diameter). Dynamic growth models, rather than directly modelling the course of values over time, predict rates of change under various conditions. The trajectories over time are then obtained by adding or integrating these rates.
}

projection equation when no inventory data are available. The effect of thinning on stand basal area growth was also examined.

\section{MATERIALS AND METHODS}

\subsection{Data}

The data used to develop the stand basal area growth system were obtained from two different sources. Initially, in the winter of 1995 the Unidade de Xestión Forestal Sostible of the University of Santiago de Compostela established a network of 223 plots in pure radiata pine plantations in Galicia. The plots were located throughout the area of distribution of this species in the study region, and were subjectively selected to represent the existing range of ages, stand densities and sites. The size of plot ranged from 625 to $1200 \mathrm{~m}^{2}$, depending on stand density, in order to achieve a minimum of 30 trees per plot. All the trees in each sample plot were labelled with a number. Two measurements of diameter at breast height $(1.3 \mathrm{~m}$ above ground level) were made at right angles to each other and to the nearest $0.1 \mathrm{~cm}$, with callipers, and the arithmetic mean of the two measurements was calculated. Total height was measured to the nearest $0.1 \mathrm{~m}$ with a digital hypsometer in a 30-tree randomized sample and in another sample including the dominant trees (the proportion of the 100 thickest trees per hectare, depending on plot size). Descriptive variables of each tree were also recorded, e.g. if they were alive or dead.

A subset of 155 and 46 of the initially established plots was remeasured in the winters of 1998 and 2004, respectively. Between each of the three inventories, 22 plots were lightly or moderately thinned once from below. These plots were also remeasured immediately before and after thinning operations, so that they were inventoried four or five times. The first sources of data were the inventories carried out in 1995, 1998, and 2004 and on the date of the thinning operations.

In addition, data from the first and second measurements of two thinning trials installed in a 12-year old stand of radiata pine were also used. Each thinning trial consisted of 12 plots of $900 \mathrm{~m}^{2}$, in which four thinning regimes were replicated on three different occasions. The four thinning treatments considered were: an unthinned control, a light thinning from below (approximately $10 \%$ of the stand basal area removed), a moderate thinning from below (approximately $25 \%$ of the stand basal area removed), and a selection thinning (selection of crop trees and extraction of their competitors, which represent approximately $20 \%$ of the stand basal area of the unthinned control). The plots were thinned immediately after plot establishment in 2003 and were re-measured two years later. The second source of data corresponds to the first and second inventories of these thinning trials.

The stand variables calculated for each inventory were: stand age $(t)$, stand basal area $(B A)$, number of trees per hectare $(N)$, dominant height $\left(H_{0}\right)$ (defined as the mean height of the 100 thickest trees per hectare), and site index ( $S$, defined as the dominant height of the stand, in meters, at a reference age of 20 years), which was obtained from the site quality system developed by Diéguez-Aranda et al. [27].

Only live trees were included in the calculations for stand basal area and number of trees per hectare. In addition, data on the number of trees per hectare and stand basal area removed in thinning operations were available. Summary statistics, including the mean, minimum, maximum, and standard deviation of these stand variables are given in Table I. 
Table I. Characteristics of the sample plots used for model fitting.

\begin{tabular}{|c|c|c|c|c|c|c|c|c|}
\hline \multirow[b]{2}{*}{ Variable } & \multicolumn{4}{|c|}{ Unthinned plots (368 inventories) } & \multicolumn{4}{|c|}{ Thinned plots (90 inventories) } \\
\hline & Mean & Min. & Max. & S.D. & Mean & Min. & Max. & S.D. \\
\hline$\overline{t \text { (years) }}$ & 23.9 & 7 & 47 & 8.9 & 19.9 & 12 & 35 & 6.7 \\
\hline$N\left(\right.$ trees $\left.\mathrm{ha}^{-1}\right)$ & 965 & 191.6 & 2048 & 566.4 & 885.8 & 378.0 & 1333.0 & 245.1 \\
\hline$B A\left(\mathrm{~m}^{2} \mathrm{ha}^{-1}\right)$ & 34.6 & 5.1 & 87.1 & 11.4 & 30.5 & 16.9 & 63.0 & 9.4 \\
\hline$H_{0}(\mathrm{~m})$ & 20.5 & 5.9 & 35.2 & 5.8 & 20.2 & 12.9 & 32.7 & 4.4 \\
\hline$S(\mathrm{~m})$ & 19.1 & 10.8 & 27.6 & 3.4 & 21.6 & 15.3 & 26.7 & 3.0 \\
\hline
\end{tabular}

\subsection{Stand basal area projection function}

Several stand basal area projection functions for thinned and unthinned stands have been reported. Many of these functions are empirically-based $[6,8,24,25,35,40,49,53,54,56,65,69]$, while others $[9,28,55,66,67]$ are derived directly from biologically-based growth functions (e.g., Korf (cited in [46]), Hossfeld [38], and Bertalanffy-Richards [11, 12,57]).

The use of dynamic equations derived from the integral form of biologically-based differential functions is highly recommended for projecting stand basal area over time since they fulfil the three previously outlined desired characteristics. Bailey and Clutter [7] proposed a technique for dynamic equation derivation that is known in forestry as the Algebraic Difference Approach (ADA), which essentially involves replacing a base-model site-specific parameter with its initialcondition solution. The main limitation of this approach is that most models derived with it are either anamorphic or have single asymptotes [7, 22]. Cieszewski and Bailey [22] extended this method and presented the Generalized Algebraic Difference Approach (GADA), which can be used to derive the same models as those derived by ADA. The main advantage of GADA is that the base equations can be expanded according to various theories about growth characteristics (e.g. asymptote, growth rate), thereby allowing more than one parameter to be site-specific and allowing derivation of more flexible dynamic equations (see [18-20,22]). GADA includes the ability to simulate concurrent polymorphism and multiple asymptotes.

\subsection{Stand basal area initialization function}

To project stand basal area by use of a projection function it is necessary to have an initial value at a given age for this variable. Usually, the initial condition value is obtained from a common forest inventory where diameter at breast height is measured; however, when this is not available, a stand basal area initialization equation is required.

After replacing the site-specific parameters of the base equation with explicit functions of $X$ (one unobservable independent variable that describes site productivity as a summary of management regimes, soil conditions, and ecological and climatic factors), we developed an initialization function for estimating stand basal area at any specific point in time. Since stand basal area depends on the age of the stand and other stand variables (theoretically the productive capacity of the site and any other measure of stand density), it is generally necessary to relate $X$ to these variables to achieve good estimates.

Compatibility between the projection and initialization functions is ensured when: (1) both are developed on the basis of the same base equation, (2) $X$ is related in linear or nonlinear form to stand variables that do not vary over time (e.g. site index), and (3) the nonsite-specific parameters of the base equation have the same value for both the initialization and projection functions. Compatibility implies that, for a given stand basal area curve obtained from the initialization function, irrespective of which point on the curve is used as the initial condition value in the projection function, the estimated stand basal area will always be a point on that curve.

The compatibility between the projection and initialization functions does not depend on the process of parameter estimation, so different methodologies can be used to estimate the parameters of both functions considering the same base model: (a) estimation of the parameters of the projection function, substitution of their values into the initialization function, and then fitting the latter to estimate the parameters that relate $X$ to stand variables that do not vary over time; (b) estimation of the parameters of the initialization function, and recovery of the implied projection function; or (c) estimation of all the parameters of the system simultaneously using an appropriate regression technique that accounts for the correlations between the righthand side endogenous variables and the error component of the lefthand side endogenous variables (this is called simultaneous equation bias) [62]. With options (a) and (b) is easier to achieve convergence on the parameter estimates, and provide the best estimates of stand basal area projection or initialization, depending on which equation is prioritized; however, this may increase the bias and the standard error of the other equation. Option (c) reduces the total system squared error, that is, it simultaneously minimizes both stand basal area projection and initialization errors. The selection of the most appropriate fitting option will depend on the forest manager, who should decide if the system will be used mainly for stand basal area projection, initialization, or a mixture of both. In this study we selected option (a), which gives priority to the projection function, because the dynamic model will be most frequently used to project stand basal area, given an initial stand condition obtained from a common forest inventory $[9,28,67]$.

\subsection{Models considered}

A large number of mathematical equations can be used to describe stand basal area growth. In the present study, three well-known growth functions in forestry applications, including stand basal area growth modelling, were selected for analysis: Korf (cited in [46]), Hossfeld [38], and Bertalanffy-Richards [11, 12,57].

On the basis of these equations, several dynamic models were formulated by use of GADA to develop the projection function. Most of the equations considered for modelling stand basal area growth did not assume anamorphic growth for this variable (e.g., [3, 30, $66,67]$; therefore, only the possible polymorphic solutions of the 
Table II. Base models and GADA formulations considered.

\begin{tabular}{|c|c|c|c|c|}
\hline Base model & $\begin{array}{l}\text { Parameter } \\
\text { related to site }\end{array}$ & Solution for $X$ with initial values $\left(t_{0}, Y_{0}\right)$ & Dynamic equation & \\
\hline \multirow{2}{*}{$\begin{array}{l}\text { Korf: } \\
Y=a_{1} \exp \left(-a_{2} t^{-a_{3}}\right)\end{array}$} & $a_{2}=X$ & $X_{0}=-\ln \left(\frac{Y_{0}}{a_{1}}\right) t_{0}^{a_{3}}$ & $Y=b_{1}\left(\frac{Y_{0}}{b_{1}}\right)^{\left(\frac{t_{0}}{T_{1}}\right)^{b_{3}}}$ & (BA1) \\
\hline & $\begin{array}{l}a_{1}=\exp (X) \\
a_{2}=b_{1}+b_{2} / X\end{array}$ & 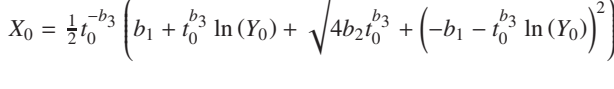 & $Y=\exp \left(X_{0}\right) \exp \left(-\left(b_{1}+b_{2} / X_{0}\right) t^{-b_{3}}\right)$ & (BA2) \\
\hline \multirow{2}{*}{$\begin{array}{l}\text { Hossfeld: } \\
Y=\frac{a_{1}}{1+a_{2} t^{-a_{3}}}\end{array}$} & $a_{2}=X$ & $X_{0}=t_{0}^{-a_{3}}\left(\frac{a_{1}}{Y_{0}}-1\right)$ & $Y=b_{1} /\left(1-\left(1-b_{1} / Y_{0}\right)\left(t_{0} / t\right)^{b_{3}}\right)$ & (BA3) \\
\hline & $\begin{array}{l}a_{1}=b_{1}+X \\
a_{2}=b_{2} / X\end{array}$ & $X_{0}=\frac{1}{2}\left(Y_{0}-b_{1}+\sqrt{\left(Y_{0}-b_{1}\right)^{2}+4 b_{2} Y_{0} t_{0}^{-b_{3}}}\right)$ & $Y=\frac{b_{1}+X_{0}}{1+b_{2} / X_{0} t^{-b_{3}}}$ & (BA4) \\
\hline \multirow{2}{*}{$\begin{array}{l}\text { Bertalanffy-Richards: } \\
Y=a_{1}\left(1-\exp \left(-a_{2} t\right)\right)^{a_{3}}\end{array}$} & $a_{2}=X$ & $X_{0}=-\ln \left(1-\left(Y_{0} / b_{1}\right)^{1 / b_{3}}\right) / t_{0}$ & $Y=b_{1}\left(1-\left(1-\left(\frac{Y_{0}}{b_{1}}\right)^{1 / b_{3}}\right)^{t / t_{0}}\right)^{b_{3}}$ & $(\mathrm{BA} 5)$ \\
\hline & $\begin{array}{l}a_{1}=\exp (X) \\
a_{3}=b_{2}+b_{3} / X\end{array}$ & $\begin{array}{l}X_{0}=\frac{1}{2}\left(\ln Y_{0}-b_{2} L_{0}+\sqrt{\left(\ln Y_{0}-b_{2} L_{0}\right)^{2}-4 b_{3} L_{0}}\right) \\
\text { with } L_{0}=\ln \left(1-\exp \left(-b_{1} t_{0}\right)\right)\end{array}$ & $Y=Y_{0}\left(\frac{1-\exp \left(-b_{1} t\right)}{1-\exp \left(-b_{1} t_{0}\right)}\right)^{\left(b_{2}+b_{3} / X_{0}\right)}$ & $(\mathrm{BA} 6)$ \\
\hline
\end{tabular}

above-mentioned equations were considered for analysis. Some of these solutions had been discarded earlier because the fitting curves performed poorly in describing the observed trends in the data. We therefore focused our efforts on six dynamic equations, the formulations of which are shown in Table II. All of the equations are base-age invariant.

General notational convention, $a_{1}, a_{2} \ldots a_{n}$ was used to denote parameters in base models, whereas $b_{1}, b_{2} \ldots b_{m}$ were used for global parameters in subsequent GADA formulations. All the GADA-based models have the general implicit form of $Y=f\left(t, t_{0}, Y_{0}, b_{1}, b_{2} \ldots b_{m}\right)$.

Models BA1, BA3 and BA5 were derived by applying GADA to the Korf, Hossfeld and Bertalanffy-Richards functions, respectively, and by considering only parameter $a_{2}$ to be site specific. In this case GADA is equivalent to ADA. Model BA1 has been used to describe stand basal area growth in many studies (e.g., [3, 9, 28, 30, 44, 66, 67]). Model BA3 is the polymorphic equation described by McDill and Amateis [48] for estimating site quality, and can also be used for stand basal area growth modelling (e.g., [30,31]). Model BA5 has also often been used in forestry applications, including stand basal area growth modelling [28,41,44,53,55], because of its theoretical flexibility. All of these models are polymorphic and have a single asymptote.

Dynamic models BA2, BA4 and BA6 were developed by considering two parameters to be site specific. Model BA2 was derived on the basis of the Korf function by considering both parameters $a_{1}$ and $a_{2}$ to be dependent on $X$. To facilitate such derivation, the base equation was re-parameterized into a more suitable form for manipulation of these two parameters, by use of $\exp (X)$ instead of $a_{1}$. Parameter $a_{2}$ was expressed as a linear function of the inverse of $X$. Model BA4 was derived by Cieszewski [19] from the Hossfeld function, by replacing $a_{1}$ with a constant plus the unobserved site variable $X$, and $a_{2}$ by $b_{2} / X$. Model BA6 was developed by Krumland and Eng [43] by expressing the asymptote as an exponential function of $X$ and the shape parameter as a linear function of the inverse of $X$.

For the base equations with two site-specific parameters, the solution for $X$ involved finding roots of a quadratic equation and selecting the most appropriate for substituting into the dynamic equation. We only used the solutions involving addition rather than subtraction of the square root because they are more likely to be real and positive [22].

In summary, both recently developed dynamic equations with two site-specific parameters and frequently used dynamic equations with only one site-specific parameter were tested. The initialization function was developed on the basis of the base growth function from which the dynamic model that provided the best results on projection was derived.

\subsection{Model fitting and validation}

The stand basal area growth system was developed in two stages: firstly, we fitted a model for projecting stand basal area over time; secondly, we attempted to develop a compatible initialization function, using option (a) (see Sect. 2.3.). If this is not possible (i.e., if the initialization function requires the inclusion of stand variables that vary over time -such as number of trees per hectare or dominant height- to achieve good estimates), compatibility is not ensured, so the "best" stand basal area initialization model should be constructed, regardless of the base function used for the stand basal area projection.

Data measurements generally contain environmental and measurement errors. If stand basal area is assumed to be error free when it is on the right-hand side of the equation, but includes error when it is on the left-hand side of the equation, a conflict exists. Therefore, stand basal areas that appear on the right-hand side of the models should represent points on the global model (estimates) that cannot be evaluated until the global parameters are estimated. However, the estimated stand basal areas must be known so that unbiased estimates of the global model parameters can be obtained [43]. Several methods have been suggested to overcome this problem (e.g., [7, 23, 33]). These have generally been applied for fitting site-quality equations and involve simultaneous estimation of the global model parameters and of the measurement and environmental errors associated with the site-specific parameters.

We used the dummy variables method proposed by Cieszewski et al. [23]. In this method, the initial conditions are specified as 
identical for all the measurements belonging to the same unthinned growth period within a single plot, hereafter the individual being investigated. During the fitting process the stand basal area corresponding to the initial age (which can be arbitrarily selected for each unthinned interval, although age zero is not allowed) is simultaneously estimated for each individual and all of the global model parameters. In the dummy variables method it is recognized that each measurement is made with error, and therefore, it seems unreasonable to force the model through any given measurement. Instead, the curve is fitted to the observed individual trends in the data.

As an example of this procedure, consider model BA1. The $Y_{0}$ variable must be substituted by a sum of terms containing a sitespecific or local parameter (an initial stand basal area) and a dummy variable for each individual:

$$
Y=b_{1}\left(\frac{\left(Y_{01} I_{1}+Y_{02} I_{2}+\ldots+Y_{0 n} I_{n}\right)}{b_{1}}\right)^{\left(\frac{t_{0}}{t_{1}}\right)^{b_{3}}}
$$

where $Y_{0 i}$ is the site-specific parameter for each individual $i$, and $I_{i}$ is a dummy variable equal to 1 for individual $i$ and 0 otherwise. The sum of terms of the initial stand basal area times the dummy variable collapses into a single parameter (an estimated stand basal area at the specified initial age) that is unique for each individual during the fitting process. The dummy variables method was programmed using the MODEL procedure of SAS/ETS ${ }^{\circledR}$ [62]. The Marquardt algorithm was used for model fitting.

Once the projection function was fitted, the shared parameters were substituted in the initialization function and the remaining unknown parameters were estimated by ordinary nonlinear least squares (ONLS) by the NLIN procedure of SAS/STAT ${ }^{\circledR}$ [63]. Only data from inventories corresponding to ages younger than 15 years were used, and it was assumed that if projections based on ages older than this threshold are required, the initial stand basal area should be obtained directly from inventory data.

The models were fitted by nonlinear least squares without considering the possible autocorrelation among the errors because of the repeated measurements on the same plots. With data from the first inventory of 223 plots and from the second and third re-measurements of 155 and 46 of these plots, respectively, the maximum of possible time correlations among residuals is practically inexistent. In addition, preliminary graphical analysis did not reveal any trend in raw residuals as a function of age lag1-residuals within the same individual for the models analyzed. Therefore, the problem of autocorrelated errors was not considered in the fitting process.

Comparison of the estimates for the different models was based on numerical and graphical analyses of the residuals. Two statistics were examined: the root mean square error (RMSE), which analyses the accuracy of the estimates in the same units as the dependent variable, and the coefficient of determination (also referred to as pseudo- $R^{2}$ when applied in nonlinear regression), which shows the proportion of the total variance of the dependent variable that is explained by the model. Although there are several shortcomings associated with use of the $R^{2}$ in nonlinear regression, the general usefulness of some global measure of model adequacy would seem to override some of those limitations ([59], p. 424). The expressions of these statistics are as follows:

$$
\begin{gathered}
\mathrm{RMSE}=\sqrt{\frac{\sum_{i=1}^{n}\left(y_{i}-\hat{y}_{i}\right)^{2}}{n-p}} \\
R^{2}=1-\frac{\sum_{i=1}^{n}\left(y_{i}-\hat{y}_{i}\right)^{2}}{\sum_{i=1}^{n}\left(y_{i}-\bar{y}\right)^{2}}
\end{gathered}
$$

were $y_{i}, \hat{y}_{i}$ and $\bar{y}$ are the observed, predicted and average values of the dependent variable, respectively, $n$ is the total number of observations, and $p$ is the number of model parameters.

Another important step in evaluating the models was to perform graphical analyses of the residuals and the appearance of the fitted curves overlaid on the trajectories of the stand basal area for each individual. Visual or graphical inspection is an essential point in selecting the most appropriate model because curve profiles may differ drastically, even though fitting statistics and residuals are similar.

If we are interested in comparing candidate models in terms of their predictive capabilities, it must be taken into account that ordinary residuals are measures of quality of fit and not of quality of future prediction ([50], p. 168) and therefore validation of the model must be carried out. For this, only a newly collected data set can be used [42]. Several methods of validation have been proposed because of the scarcity of such data (e.g., splitting the data set or crossvalidation, double cross-validation), although they seldom provide any additional information compared with the respective statistics obtained directly from models built from entire data sets [42]. Moreover, according to Myers ([50], p. 170) and Hirsch [37] the final estimation of the model parameters should come from the entire data set because the estimates obtained with this approach will be more precise than those obtained from the model fitted from only one portion of the data. We therefore decided to defer model validation until a new data set is available for assessing the quality of the predictions.

\subsection{Thinning effect on basal area growth}

Theoretically, when a forest stand is thinned, its growth characteristics and dynamics change (e.g. [64]). Several studies have shown that basal area growth rates in thinned stands exceed those of unthinned stands with the same characteristics (e.g. [5, 6, 34, 35, 52, 53, 56]). Two approaches have been commonly used to consider the effect of thinning operations on stand basal area growth:

1. Development of different basal area growth functions for different types of stands (unthinned and thinned) that have the same mathematical structure but that have been parameterized using different data sets $[40,52,69,71]$.

2. Inclusion of a thinning response function that expresses the basal area growth of a thinned stand as a product of a reference growth and the thinning response function [39]: the reference growth accounts for the factors affecting stand growth in unthinned stands while the thinning response function predicts the relative growth response following thinning. Several attempts have been made to model the thinning response on the growth of the remaining basal area $[5,8,17,30,35,54,56]$, mainly with stands derived from plantations.

In this study, we used the first approach to take into account the effect of thinning on stand basal area growth, by employing dummy categorical variables. To compare the differences between basal area growth in thinned and unthinned plots, we used the non-linear extra sum of squares method for detecting simultaneous homogeneity among parameters for both treatments (see Bates and Watts [10], pp. 103-104). If the homogeneity of parameters test reveals significant differences between silvicultural treatments, separate basal area growth models are necessary for each treatment. 
Table III. Parameter estimates, approximated standard errors, and goodness-of-fit statistics for the models analyzed.

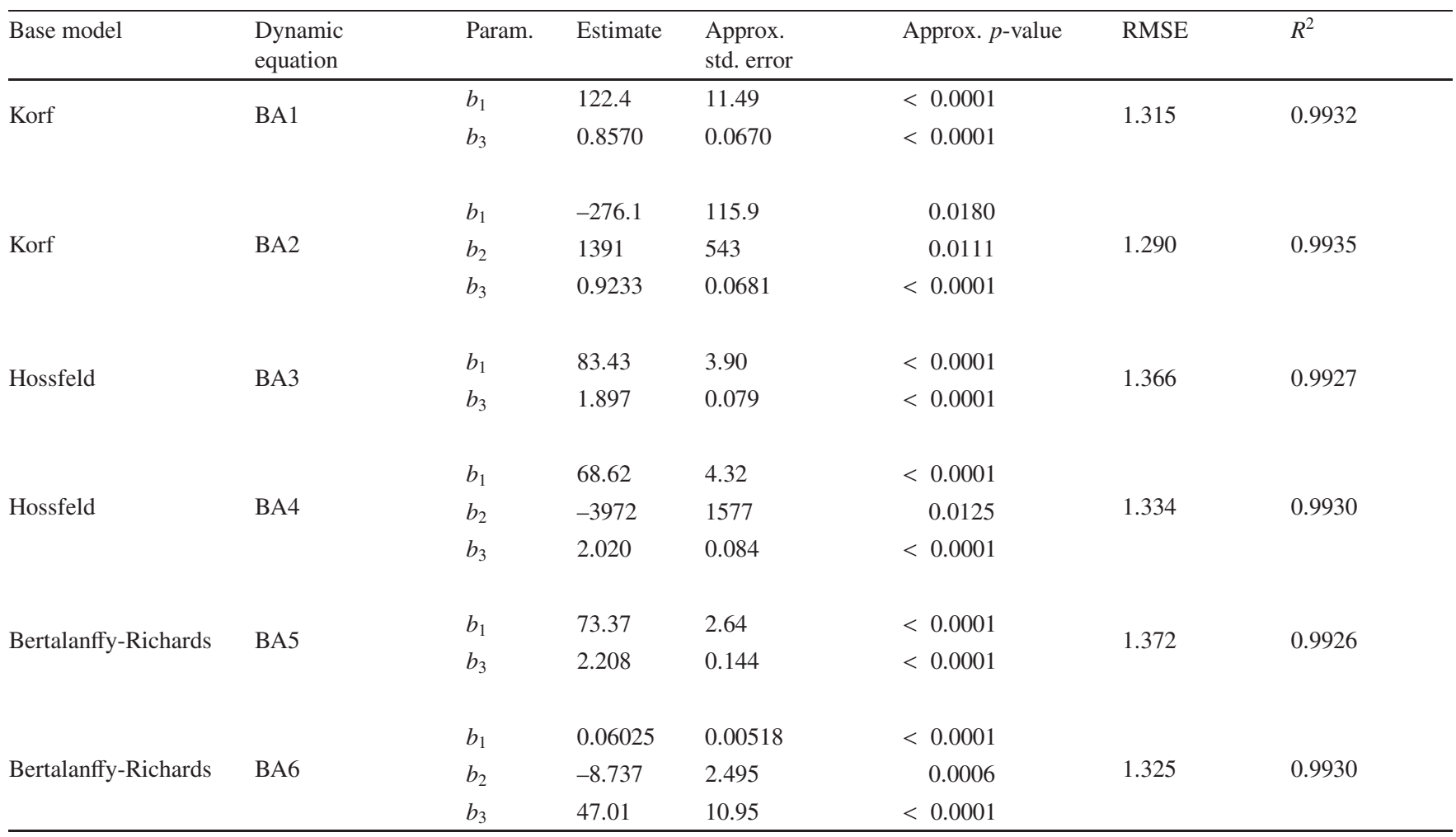

\section{RESULTS AND DISCUSSION}

\subsection{Stand basal area projection function}

The parameter estimates for each model, including their approximated standard errors and $p$-values, and the corresponding goodness-of-fit statistics are shown in Table III. Among all the equations analyzed, the models with only one sitespecific parameter (models BA1, BA3, and BA5) provided slightly poorer results for the goodness-of-fit statistics than the corresponding models with two site-specific parameters (models BA2, BA4, and BA6, respectively) derived from the same base equation. All of the models accounted for approximately 99.3\% of the total variation and provided a random pattern of residuals around zero with homogeneous variance and no discernable trends.

As previously commented, visual or graphical inspection of the models was considered an essential point in selecting the most accurate representation. Therefore, plots showing the curves for stand basal areas of 15,30,45, and $60 \mathrm{~m}^{2} \mathrm{ha}^{-1}$ at 20 years overlaid on the trajectories of observed values over time, were examined (Fig. 1). The equations derived from the same base model (with one and two site-specific parameters) were overlaid on the same graph. This comparison allowed us to discard some models that did not provide a good description of the trends in the data. Models BA3 and BA5, derived considering only one parameter to be site-specific in the base models of Hossfeld and Bertalanffy-Richards, respectively, were significantly poorer at describing the data than the corresponding two site-specific parameter models BA4 and BA6. The asymptotic values of models BA3 and BA5 appeared to be too small, especially for the highest growth curves, in which they clearly cross the observed values of stand basal area over time. Model BA1 derived from the base model of Korf by considering one parameter to be site-specific, was the only model that behaved in a similar way to the corresponding model with two site-specific parameters (BA2).

Within the group with two site-specific parameters all models provided similar results, although model BA2 seemed to provide slightly better graphical descriptions, especially for juvenile ages. The asymptotic value for the highest stand basal area growth curves generated with model BA2 $\left(125.4 \mathrm{~m}^{2} \mathrm{ha}^{-1}\right)$ appeared to be slightly high, although this does not have any apparently serious consequences for the quality of the predictions within the rotation ages of 25-35 years usually applied for radiata pine stands in Galicia [14,58]. Moreover, the curves seem reliable beyond the rotation age, as judged by the estimations of stand basal area overlaid on the trajectories of the observed values over time (Fig. 1). Similar results were obtained by Barrio et al. [9] in developing a basal area projection function for Pinus pinaster stands in Galicia.

In summary, taking into account the adequate graphs provided by model BA2 (Fig. 1) as well as the values of the goodness-of-fit statistics obtained in the fitting process (Tab. III), the BA2 dynamic model derived from the Korf equation was selected for projecting the stand basal area of 
Korf base model (BA1, BA2)

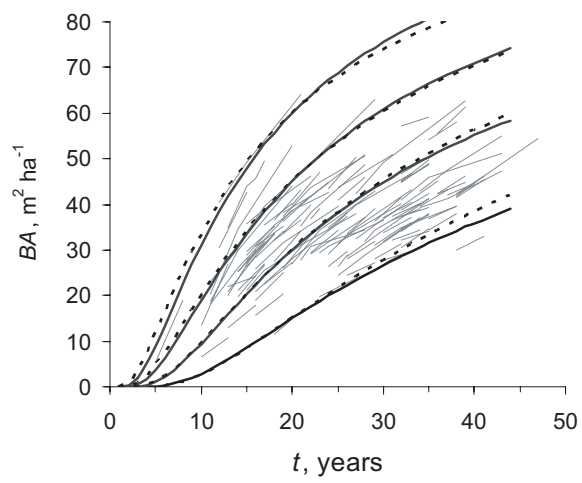

Bertalanffy-Richards base model (BA5, BA6)

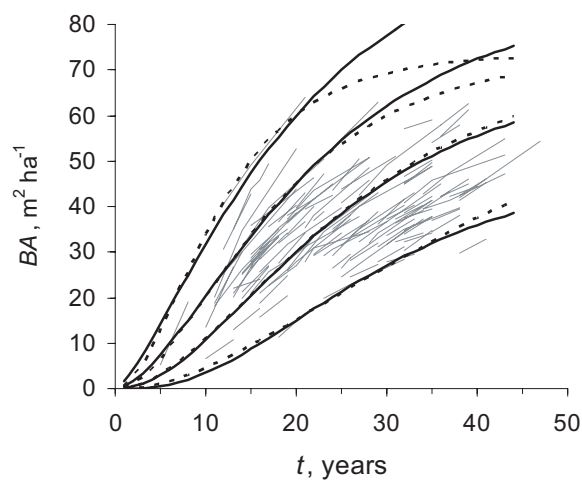

Hossfeld base model (BA3, BA4)

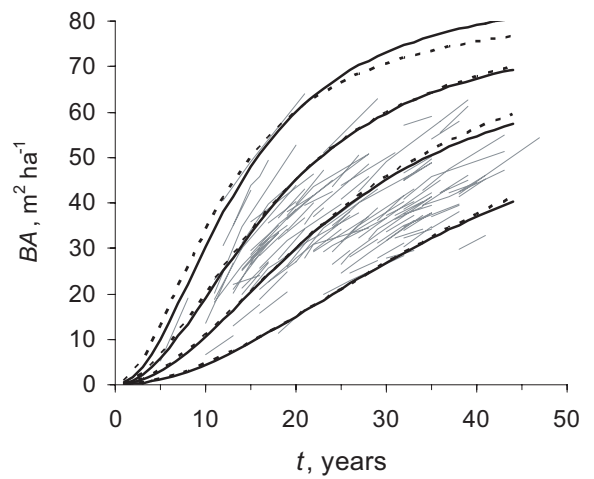

Figure 1. Stand basal area growth curves for stand basal areas of 15, 30, 45 and $60 \mathrm{~m}^{2} \mathrm{ha}^{-1}$ at 20 years for the two- (solid line) and one-sitespecific models (dashed line) overlaid on the trajectories of observed values over time.

radiata pine plantations in Galicia. The model is expressed as follows:

$$
\begin{aligned}
\hat{Y}= & \exp \left(X_{0}\right) \exp \left[-\left(-276.1+1391 / X_{0}\right) t^{-0.9233}\right], \text { with } \\
X_{0}= & 0.5 t_{0}^{-0.9233}\left\{-276.1+t_{0}^{0.9233} \ln \left(Y_{0}\right)\right. \\
& \left.+\sqrt{4 \times 1391 t_{0}^{0.9233}+\left[276.1-t_{0}^{0.9233} \ln \left(Y_{0}\right)\right]^{2}}\right\}
\end{aligned}
$$

\subsection{Thinning effect on basal area growth}

Equation (4) provided the best overall representation of stand basal area development considering all the growth intervals both for thinned and unthinned plots, and explained a high percentage of the total variance $(99.35 \%)$. However, it was also important to know if there were differences in the unitarea basal area growth between thinned and unthinned stands, which would lead to inconsistent and biased stand basal area projections.

The effect of thinning was analyzed considering a new dummy variable. The non-linear extra sum of squares method used for detecting simultaneous homogeneity among parameters for both treatments did not reveal any significant differences (the null hypothesis of a unique stand basal area projection model for thinned and unthinned stands was accepted

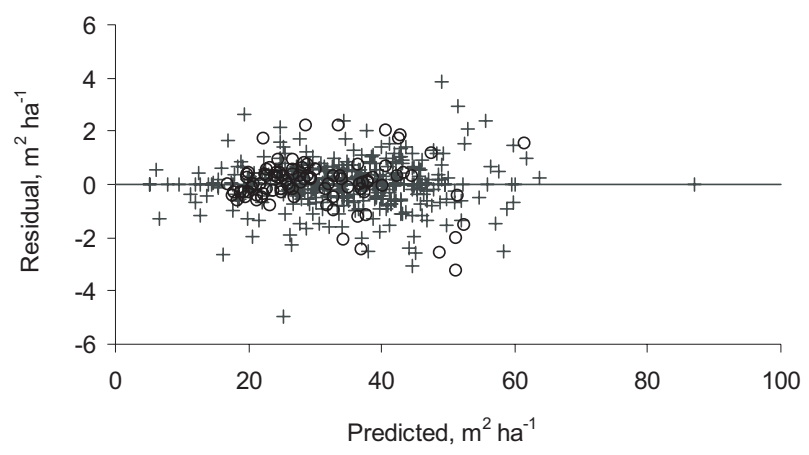

Figure 2. Plot of residuals versus predicted values of the stand basal area projection function BA2 for unthinned (plus signs) and thinned plots (circles).

because of a insignificant $F$-value of 2.57 at $\alpha=0.05$ ). Therefore, Equation (4) was considered for projecting stand basal area for both thinned and unthinned stands. Examination of the residuals - by applying Equation (4) to thinned and unthinned plots (Fig. 2) - did not indicate any trends in terms of underestimation of the stand basal area of unthinned plots or overestimation of the stand basal area of thinned plots.

All these results suggest that, for our data set, the stand basal area growth pattern after thinning is close to the stand basal area growth pattern of a stand with similar stand 

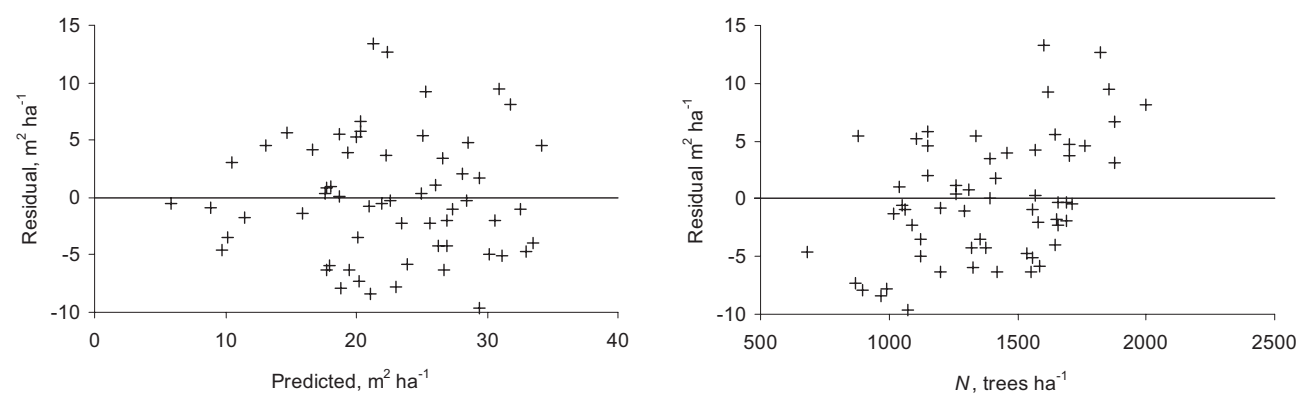

Figure 3. Plot of residuals versus predicted values and number of trees per hectare of the stand basal area initialization function derived from model BA2 considering only site index as explanatory stand variable.

conditions but that has not been recently treated. Since the data used to develop the model were obtained from both thinned and unthinned stands, it seems reasonable to assume that the thinning effect is built into the model. This is in accordance with the studies of Clutter and Jones [25], Cao et al. [13], Matney and Sullivan [47] and Barrio et al. [9] for different pine species, which have demonstrated that there is no difference in the unit-area basal area growth in thinned and unthinned stands of the same age, site index and stand basal area.

This result, however, contradicts those of some studies of stand basal area growth of radiata pine in other regions. Espinel et al. [29] used a different formulation for estimating the stand basal area growth before and after thinning operations in the Basque Country (Northern Spain). A similar approach was also reported by Woollons and Hayward [69] for radiata pine in New Zealand. It has also been demonstrated for Chilean radiata pine plantations that the stand basal area of the thinned plots exceeds that of the unthinned counterparts [61]. In this case, a thinning response function depending on the intensity of thinning, the time since last thinning and the age of the stand at the thinning, was included in the projection model.

The apparently contradictory results of the thinning effect on stand basal area growth for radiata pine plantations for Galicia and these other regions may be at least partly attributed to the experimental data sets used. In the present study we used data derived from plots or thinning trials where mainly low or moderate thinnings were carried out, whereas in New Zealand and Chile, heavy thinnings are usually applied. Nevertheless, it must be taken into account that the studies involving thinning experiments in even-aged stands showed inconsistent results in terms of the effects of stand density variation on stand basal area growth ([26], p. 68).

In summary, the assumption of no difference in the per unitarea basal area growth between thinned and unthinned stands of the same age, site index, and stand basal area holds for our data set, and therefore it was not necessary to incorporate any thinning effect in the dynamic model (Eq. (4)).

\subsection{Stand basal area initialization function}

Once the stand basal area projection function was selected, we focused our efforts on developing a compatible stand basal area initialization function from Equation (4). Parameters $b_{1}$, $b_{2}$, and $b_{3}$ were substituted in the base equation of Korf (after replacing the site-specific parameters of the base equation with the explicit function of $X$ ) with the values obtained for the projection function, and the unknown site-dependent function $X$ was related to site variables. Firstly, $X$ was substituted by a power function of site index. The inclusion of site index in this relationship is consistent with the philosophy of GADA, and directly warrants compatibility between the projection and initialization functions because site index is considered as a stable stand attribute over time. Under these conditions, the initialization function explained $61.8 \%$ of the total variance, with a RMSE or $5.315 \mathrm{~m}^{2} \mathrm{ha}^{-1}$, and provided a pattern of residuals with homogeneous variance but with significant trends both against predicted stand basal area and observed number of trees per hectare (Fig. 3).

We therefore analyzed the inclusion into the previous model of other stand variables that may affect the amount of stand basal area at any specific moment (theoretically variables related to stand density), in order to improve the estimation capability of the initialization function at the expense of losing compatibility. When the inverse of the number of trees per hectare was included together with a power function of the site index, the initialization equation explained $70.3 \%$ of the variance, with a RMSE of 4.688, and provided a random pattern of residuals around zero with no detectable significant trends, for either predicted stand basal area or observed number of trees per hectare. This formulation provided significantly better estimates of stand basal area for any specific point in time.

The important improvement (almost an increase of $12.1 \%$ in $R^{2}$ and a reduction of $11.8 \%$ in RMSE) achieved by including the number of trees per hectare into the initialization function led us to discard compatibility within the stand basal area growth system. At this point, it seemed unnecessary to force the development of the initialization equation considering the same base model of the projection equation. Following the methods of several authors (e.g., [6,54], we analyzed several linear and nonlinear models with different explanatory stand variables (age, dominant height, site index, number of trees per hectare, relative spacing index, and combinations of these variables). A linear model with stand age, site index, and number of trees per hectare as independent variables behaved best. This model explained $72.5 \%$ of the total variance of the data (15.2\% more than the compatible model), with a RMSE 

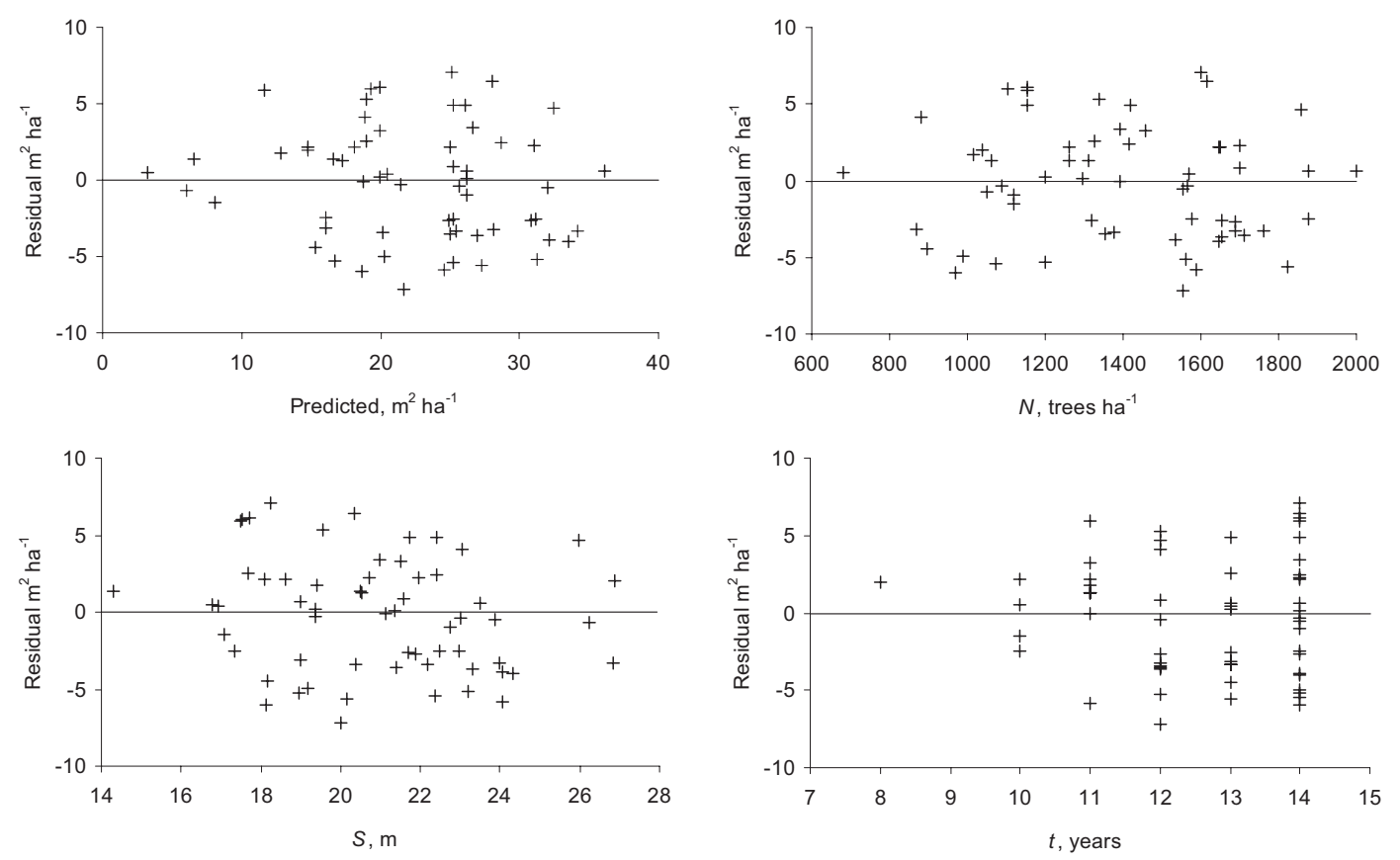

Figure 4. Plot of residual versus predicted values and the observed explanatory variables age, site index and number of trees per hectare of the stand basal area initialization function selected (Eq. (5)).

of $4.595 \mathrm{~m}^{2} \mathrm{ha}^{-1}$ (13.5\% smaller than the compatible model), and behaved logically: older stands on better sites and with more trees per unit-area achieved higher values of stand basal area. This model also provided a random pattern of residuals around zero with no detectable significant trends for predicted stand basal area and the observed explanatory variables stand age, site index, and number of trees per hectare (Fig. 4).

The finally recommended initialization equation for radiata pine plantations in Galicia is:

$$
\hat{Y}=-52.23+2.676 t+1.306 S+0.0101 N
$$

where $t$ is the age of the stand (years), $S$ the site index (m, defined as the dominant height of the stand at the reference age of 20 years [27]), and $N$ the number of trees per hectare.

\section{CONCLUSIONS}

Three well-known growth functions were considered for developing a stand basal area growth system for radiata pine plantations in northwestern Spain. Among the six dynamic equations finally evaluated for stand basal area projection, the GADA formulation from the Korf base model in which parameters $a_{1}$ and $a_{2}$ are considered to be site-specific behaved best. Selection of the dynamic model was based on both numerical analysis and graphical representation of the fitted curves overlaid on the trajectories of the observed stand basal area over time. The selected equation allowed simulation of concurrent polymorphism and multiple asymptotes, two desirable characteristics of growth equations. Furthermore, the dummy variables method used for model fitting is a base-age invariant method that accounts for site-specific and global effects and fits the curves to observed individual trends in the data.

A linear stand basal area initialization function, in which stand age, site index and number of trees per hectare were considered as explanatory variables, was also developed. The stand basal area system is not compatible; however, this is not a major problem for most applications, because the initialization function would only be used to provide an initial value at a given age for this variable, and not to project stand basal area over time.

For the data set analyzed, the initial stand basal area and age provided sufficient information about the future trajectory of the stand basal area. It was therefore not necessary to consider the thinning effect in the dynamic model for projecting stand basal area in thinned stands. These results were not consistent with those obtained by other authors for radiata pine plantations in other regions, and may be due to the scarcity of intensively treated plots in the experimental data.

Acknowledgements: This study was financed by the Spanish Ministry of Education and Science; project No. AGL2004-07976-C02-01. We thank Dr. Christine Francis for correcting the English grammar of the text.

\section{REFERENCES}

[1] Álvarez Álvarez P., Viveros forestales y uso de planta en repoblación en Galicia, Ph.D. thesis, Universidade de Santiago de Compostela, 2004.

[2] Álvarez González J.A., Castedo F., Ruiz A.D., López C., Gadow K.v., A two-step mortality model for even-aged stands of 
Pinus radiata D. Don in Galicia (Northwestern Spain), Ann. For. Sci. 61 (2004) 439-448.

[3] Amaro A., Reed D.D., Themido I., Tomé M., Stand growth modelling for first rotation Eucalyptus globulus Labill. in Portugal, in: Amaro A., Tomé M. (Eds.), Empirical and process-based models for forest tree and stand growth simulation, 1997, pp. 99-110.

[4] Amaro A., Tomé M., Themido I., ALBA, un modelo de crescimento em área basal para povoamentos de eucalipto, in: Puertas F., Rivas M. (Eds.), II Congreso Forestal Español-Irati 97, 1997, vol. IV, pp. 39-44.

[5] Amateis R.L., Modeling response to thinning in loblolly pine plantations, South. J. Appl. For. 24 (2000) 17-22.

[6] Amateis R.L., Radtke P.J., Burkhart H.E., TAUYIELD: A standlevel growth and yield model for thinned and unthinned loblolly pine plantations, Va. Polytech. Inst. State Univ. Sch. For. Wildl. Resour. Report No. 82, 1995.

[7] Bailey R.L., Clutter J.L., Base-age invariant polymorphic site curves, For. Sci. 20 (1974) 155-159.

[8] Bailey R.L., Ware K.D., Compatible basal area growth and yield model for thinned and unthinned stands, Can. J. For. Res. 13 (1983) 563-571.

[9] Barrio M., Castedo F., Diéguez-Aranda U., Álvarez González J.G., Parresol B.R., Rodríguez R., Development of a basal area growth system for maritime pine in northwestern Spain using the generalized algebraic difference approach, Can. J. For. Res. 36 (2006) 1461-1474.

[10] Bates D.M., Watts D.G., Nonlinear regression analysis and its applications, John Wiley \& Sons, New York, 1988.

[11] Bertalanffy L.v., Problems of organic growth, Nature 163 (1949) $156-158$.

[12] Bertalanffy L.v., Quantitative laws in metabolism and growth, Q. Rev. Biol. 32 (1957) 217-231.

[13] Cao Q.V., Burkhart H.E., Lemin R.C. Jr., Diameter distributions and yields of thinned loblolly pine plantations, Va. Polytech. Inst. State Univ. Sch. For.Wildl. Resour. Publ. FWS-1-82, 1982.

[14] Castedo F., Modelo dinámico de crecimiento para las masas de Pinus radiata D. Don en Galicia. Simulación de alternativas selvícolas con inclusión del riesgo de incendio, Ph.D. thesis, Universidad de Santiago de Compostela, 2004.

[15] Castedo F., Álvarez González J.G., Construcción de una tarifa de cubicación con clasificación de productos para Pinus radiata D. Don en Galicia basada en una función de perfil del tronco, Invest. Agrar.: Sist. Recur. For. 9 (2000) 253-268.

[16] Castedo F., Diéguez-Aranda U., Barrio M., Sánchez Rodríguez M., Gadow K.v., A generalized height-diameter model including random components for radiata pine plantations in Northwestern Spain, For. Ecol. Manage. 229 (2006) 202-213.

[17] Chikumbo O., Mareels I.M., Turner B.J., Predicting stand basal area in thinned stands using a dynamic model, For. Ecol. Manage. 116 (1999) 175-187.

[18] Cieszewski C.J., Three methods of deriving advanced dynamic site equations demonstrated on inland Douglas-fir site curves, Can. J. For. Res. 31 (2001) 165-173.

[19] Cieszewski C.J., Comparing fixed-and variable-base-age site equations having single versus multiple asymptotes, For. Sci. 48 (2002) 7-23.

[20] Cieszewski C.J., Developing a well-behaved dynamic site equation using a modified Hossfeld IV function $Y 3=(\mathrm{axm}) /(c+x \mathrm{~m}-1)$, a simplified mixed-model and scant subalpine fir data, For. Sci. 49 (2003) 539-554.

[21] Cieszewski C.J., GADA derivation of dynamic site equations with polymorphism and variable asymptotes from Richards, Weibull, and other exponential functions. University of Georgia PMRC-TR 2004-5, 2004.
[22] Cieszewski C.J., Bailey R.L., Generalized algebraic difference approach: theory based derivation of dynamic equations with polymorphism and variable asymptotes, For. Sci. 46 (2000) 116-126.

[23] Cieszewski C.J., Harrison M., Martin S.W., Practical methods for estimating non-biased parameters in self-referencing growth and yield models, University of Georgia PMRC-TR 2000-7, 2000.

[24] Clutter J.L., Compatible growth and yield models for loblolly pine, For. Sci. 9 (1963) 354-371.

[25] Clutter J.L., Jones E.P., Prediction of growth after thinning in oldfield slash pine plantations, USDA For. Serv. Res. Pap. SE-217, 1980.

[26] Clutter J.L., Fortson J.C., Pienaar L.V., Brister H.G., Bailey R.L., Timber management: a quantitative approach, John Wiley \& Sons, Inc. New York, 1983.

[27] Diéguez-Aranda U., Burkhart H.E., Rodríguez R., Modelling dominant height growth of radiata pine (Pinus radiata D. Don) plantations in northwestern Spain, For. Ecol. Manage. 215 (2005) 271284.

[28] Diéguez-Aranda U., Castedo F., Álvarez González J.G., Funciones de crecimiento en área basimétrica para masas de Pinus sylvestris L. procedentes de repoblación en Galicia, Invest. Agrar.: Sist. Recur. For. 14 (2005) 253-266.

[29] Espinel S., Cantero A., Sáenz D., Un modelo de simulación para rodales de Pinus radiata D. Don en el País Vasco, in: Puertas F., Rivas M. (Eds.), II Congreso Forestal Español- Irati 97, 1997, vol. IV, pp. 201-206.

[30] Falcao A., DUNAS - A growth model for the National Forest of Leiría, in: Amaro A., Tomé M. (Eds.), Empirical and process-based models for forest tree and stand growth simulation, 1997, pp. 145153.

[31] Fonseca T.J.F., Modelação do crescimento, mortalidade e distribuição diamétrica, do pinhal bravo no vale do Tâmega, Ph.D. thesis, Universidade de Trás-os-Montes e Alto Douro, 2004.

[32] Gadow K.v., Real P., Álvarez González J.G., Modelización del crecimiento y la evolución de los bosques, IUFRO World Series, vol. 12, Vienna, 2001.

[33] García O., A stochastic differential equation model for the height growth of forest stands, Biometrics 39 (1983) 1059-1072.

[34] Hamilton C.J., The effects of high intensity thinning on yield, Forestry 54 (1981) 1-15.

[35] Hasenauer H., Burkhart H.E., Amateis R.L., Basal area development in thinned and unthinned loblolly pine plantations, Can. J. For. Res. 27 (1997) 265-271.

[36] Hein S., Dhôte J.F., Effect of species composition, stand density and site index on the basal area increment of oak trees (Quercus sp.) in mixed stands with beech (Fagus sylvatica L.) in Northern France, Ann. For. Sci. 63 (2006) 457-467.

[37] Hirsch R.P., Validation samples, Biometrics 47 (1991) 1193-1194.

[38] Hossfeld J.W., Mathematik für Forstmänner, Ökonomen und Cameralisten (Gotha, 4. Bd., S. 310), 1822.

[39] Hynynen J., Predicting the growth response to thinning for Scots pine stands using individual-tree growth models, Silva. Fenn. 29 (1995) 225-247.

[40] Knoebel B.R., Burkhart H.E., Beck D.E., A growth and yield model for thinned stands of yellow-poplar, For. Sci. Monograph 27, 1986.

[41] Kotze H., Vonck D., A growth simulator and pruning scheduler for Pinus patula in Mpumalanga-North Province, South Africa, in: Amaro A., Tomé M. (Eds.), Empirical and process-based models for forest tree and stand growth simulation, 1997, pp. 205-221.

[42] Kozak A., Kozak R.A., Does cross-validation provide additional information in the evaluation of regression models? Can. J. For. Res. 33 (2003) 976-987.

[43] Krumland B., Eng H., Site index systems for major young-growth forest and woodland species in northern California, Cal. Dep. Forestry and Fire Protection, Calif. For. Rep. No. 4, 2005. 
[44] Lei Y., Modelling forest growth and yield of Eucalyptus globulus Labill. in central-interior Portugal, Ph.D. thesis, Universidade de Trás-os-Montes e Alto Douro, 1998.

[45] López Sánchez C.A., Gorgoso J., Castedo F., Rojo A., Rodríguez R., Álvarez J.G., Sánchez F., A height-diameter model for Pinus radiata D. Don in Galicia (Northwest Spain), Ann. For. Sci. 60 (2003) 237-245.

[46] Lundqvist B., On the height growth in cultivated stands of pine and spruce in Northern Sweden, Medd. Fran Statens Skogforsk. Band 47 (1957) 1-64.

[47] Matney T.G., Sullivan A.D., Compatible stand and stock tables for thinned and unthinned loblolly pine stands, For. Sci. 28 (1982) 161171.

[48] McDill M.E., Amateis R.L., Measuring forest site quality using the parameters of a dimensionally compatible height growth function, For. Sci. 38 (1992) 409-429.

[49] McTague J.P., Bailey R.L., Compatible basal area and diameter distribution models for thinned loblolly pine plantations in Santa Catarina, Brazil, For. Sci. 33 (1987) 43-51.

[50] Myers R.H., Classical and modern regression with applications, 2nd ed., Duxbury Press, Belmont, California, 1990.

[51] Northway S.M., Fitting site index equations and other selfreferencing functions, For. Sci. 31 (1985) 233-235.

[52] Pienaar L.V., An approximation of basal area growth after thinning based on growth in unthinned plantations, For. Sci. 25 (1979) 223232.

[53] Pienaar L.V., Shiver B.D., An analysis and models of basal area growth in 45-year-old unthinned and thinned slash pine plantation plots, For. Sci. 30 (1984) 933-942.

[54] Pienaar L.V., Shiver B.D., Basal area prediction and projection equations for pine plantations, For. Sci. 32 (1986) 626-633.

[55] Pienaar L.V., Turnbull K.J., The Chapman-Richards generalization of von Bertalanffy's growth model for basal area growth and yield in even-aged stands, For. Sci. 19 (1973) 2-22.

[56] Pienaar L.V., Shiver B.D., Grider G.E., Predicting basal area growth in thinned slash pine plantations, For. Sci. 31 (1985) 731-741.

[57] Richards F.J., A flexible growth function for empirical use, J. Exp. Bot. 10 (1959) 290-300.

[58] Rodríguez R., Sánchez F., Gorgoso J., Castedo F., López C., Gadow K.v., Evaluating standard treatment options for Pinus radiata plantations in Galicia (north-western Spain), Forestry 75 (2002) 273-284.

[59] Ryan T.P., Modern regression methods, John Wiley \& Sons, New York, 1997.

[60] Sánchez F., Rodríguez R., Rojo A., Álvarez J.G., López C., Gorgoso J., Castedo F., Crecimiento y tablas de producción de Pinus radiata D. Don en Galicia, Invest. Agrar.: Sist. Recur. For. 12 (2003) 65-83.

[61] Sánchez J., Methodology to increase resolution of the Growth and Yield simulator for Pinus radiata D. Don in Chile, in: Álvarez J.G., Goulding C., Rojo A., Rodríguez R., Zoralioglu T., Ruiz A.D. (Eds.), Proceedings of the IUFRO Conference: The economics and management of high productivity plantations, 2004.

[62] SAS Institute Inc., SAS/ETS ${ }^{\circledR} 9.1$ User's Guide. Cary, NC: SAS Institute Inc., 2004.

[63] SAS Institute Inc., SAS/STAT ${ }^{\circledR} 9.1$ User's Guide. Cary, NC: SAS Institute Inc., 2004.

[64] Sharma M., Smith M., Burkhart H.E., Amateis R.L. Modeling the impact of thinning on height development of dominant and codominante trees, Ann. For. Sci. 63 (2006) 349-354.

[65] Sullivan A.D., Clutter J.L., A simultaneous growth and yield model for loblolly pine, For. Sci. 18 (1972) 76-86.

[66] Tomé M., Falcao A., Amaro A., Globulus V1.0.0: A regionalised growth model for Eucalypt plantations in Portugal, in: Ortega A., Gezan S. (Eds.), Proceedings of the IUFRO Conference: Modelling growth of fast-grown tree species, 1997, pp. 138-145.

[67] Tomé M., Ribeiro F., Soares P., O modelo Globulus 2.1, Universidad Técnica de Lisboa-ISA, Relatórios Técnico-científicos do GIMREF $\mathrm{n}^{\circ} 1,2001$.

[68] Van Laar A., Akça A., Forest Mensuration. Cuvillier Verlag, Göttingen, 1997.

[69] Woollons R.C., Hayward W.J., Revision of a growth and yield model for radiata pine in New Zealand, For. Ecol. Manage. 11 (1985) 191-202.

[70] Xunta de Galicia, O monte galego en cifras. Dirección Xeral de Montes e Medio Ambiente Natural, Consellería de Medio Ambiente, Santiago de Compostela, 2001.

[71] Zarnoch S.J., Feduccia D.P., Baldwin V.C., Dell T.R., Growth and yield predictions for thinned and unthinned slash pine plantations on cutover sites in the West Gulf region, USDA Forest Service Res. Pap. SO-264, 1991. 